\title{
Online Learning during Covid-19: What is the Most Effective Platform for Teaching and Learning Mathematics?
}

\author{
Mela Aziza ${ }^{1, a)}$ \\ ${ }^{1}$ Institut Agama Islam Negeri Bengkulu \\ 4 Raden Fatah Street, Pagar Dewa, Selebar, Kota Bengkulu, Bengkulu, Indonesia 38211 \\ ${ }^{\text {a) }}$ ela.aziza@iainbengkulu.ac.id
}

\begin{abstract}
The purpose of this research was to find how the first online learning implementation in the Department of Mathematics Education in The Islamic State Institute of Bengkulu during the Covid-19 pandemic. This research was qualitative research which was conducted in July as an evaluation of the first online learning from March until July. 90 students were chosen by purposive sampling and then given an online questionnaire. The results showed that there were some mathematical courses students took in the Even Semester 2019/2020. The platforms used by lecturers while teaching Mathematics were 39.6\% WhatsApp Group, 22\% Google Classroom, 13.2\% Cisco Webex, and $25.2 \%$ others. Platforms that were felt effective as online learning applications were 52.7\% Cisco Webex, $26.4 \%$ WhatsApp Group, 9.9\% Zoom meeting, 5.5\% Google Classroom, and $5.5 \%$ others. This is felt to be effective because it does not consume a lot of data packages, has a strong signal, and can be accessed at any time (Whats App Group and Google Classroom). In addition, this platform can be used for live conferencing / video calls using whiteboards which are deemed effective for teaching math material (Cisco Webex). However, several obstacles were found during the implementation of online learning, namely difficulties in obtaining sufficient internet data packages; limited network; difficult assignments and assessments; less effective teaching methods; and use of multiple applications.
\end{abstract}

Keywords: Covid-19; Online Learning; Platforms for Teaching and Learning

\begin{abstract}
Abstrak. Tujuan penelitian ini adalah untuk mengetahui bagaimana pelaksanaan serta kendala pembelajaran online pertama kali di program studi Pendidikan Matematika IAIN Bengkulu di masa pandemi Covid-19. Penelitian ini adalah penelitian kualitatif yang dilakukan di bulan Juli sebagai salah satu bentuk evaluasi pembelajaran online dari bulan Maret sampai Juli. Sampel yang dipilih dengan purposive sampling adalah 90 mahasiswa Tadris Matematika yaitu 32 semester II, 35 Semester IV, dan 23 Semester VI. Data dikumpulkan menggunakan kuesioner online dan kemudian diolah secara deskriptif. Dari data diperoleh bahwa ada beberapa mata kuliah matematika yang diambil di semester Genap 2019/2020 (Februari- Juli) yaitu Geometri analitik, Analisis real, Analisis Vektor, Geometri Transformasi, Persamaan Diferensial Biasa, Aljabar Linear, Struktur Aljabar, Geometri analitik, Riset Operasi, Kalkulus 2, Statistika, Trigonometri, Matematika SMP, dan Matematika Terapan. Adapun platform yang digunakan dosen selama mengajar mata kuliah Matematika adalah 39.6\% WhatsApp Group, 22\% adalah Google Classroom, 13.2\% Cisco Webex, dan $25.2 \%$ lainnya. Platform yang dirasakan efektif sebagai aplikasi pembelajaran online adalah 52.7\% Cisco webex, $26.4 \%$ WhatsApp Group, 9.9\% Zoom meeting, 5.5\% Google Classroom, dan 5.5\% lainnya. Hal ini dirasakan efektif karena tidak menghabiskan paket data yang banyak, sinyal yang kuat dan bisa diakses kapan pun (WhatsApp Group dan Google Classroom). Selain itu, platform ini bisa digunakan untuk live conference/video call dengan menggunakan whiteboard yang dirasa efektif untuk mengajarkan materi matematika (Cisco Webex). Namun, beberapa kendala ditemukan selama pelaksanaan pembelajaran online yaitu kesulitan mendapatkan paket data internet; jaringan yang terbatas; penugasan dan penilaian yang sulit; metode mengajar yang kurang efektif; dan penggunaan beberapa aplikasi.
\end{abstract}

Kata kunci: Covid-19; Pembelajaran Online; Platform untuk Pembelajaran 


\section{INTRODUCTION}

At the end of 2019, the world was intensified by the presence of an unknown pneumonia disease in a city in China, Wuhan (Sharma, 2020). Within a few months of the incident, almost all countries around the world were affected by the outbreak which became known as Covid-19. WHO noted that there were at least 216 countries affected by this outbreak, including Indonesia (WHO, n.d.). As of March 29, 2020, there have been 1285 cases found to date November 18, 2020, there is a significant increase, namely 474,455 confirmed cases of covid, of which 60,426 active cases, 398,636 recovered, and 15393 died. 34 Provinces in Indonesia have found various cases including in Bengkulu province, there are 1,396 cases (Covid19.go.id, n.d.)

The increasing number of positive Covid-19 numbers has made the Indonesian government take various policies to prevent the spread of the Covid-19 virus, especially policies in education. As of March 2020, the government requires all learning to be done online (Zhafira et al., 2020) or online/virtual (Khasanah et al., 2020), or distance learning (Herliandry et al., 2020) from the most basic level (Education Early childhood) to higher education (Higher Education). Not only students are required to study at home, but students also have to do online lectures. This is done to implement the government's recommendation to stay at home, work from home, and social distancing. Although several colleges or universities such as the Open University (UT) have conducted online tutorials long before this pandemic, UT is still preparing for webinar tutorial technology as a substitute for face-to-face tutorials (Khasanah et al. ., 2020). This shows that universities that have already implemented online / online/virtual learning still have to prepare a lot of things to deal with a full learning policy at home, especially universities that will implement online learning for the first time. There need to be adaptations and adjustments in each unit and educational element involved in online learning that is carried out to keep the learning wheels running (Herliandry et al., 2020).

Online learning is learning that utilizes internet networks (Zhafira et al., 2020) and technology (Gunawan et al., 2020) in carrying out all learning processes. Herliandry et al. (2020) explain that online learning is a learning process, both learning and collecting tasks that can be done without time and space limitations by utilizing technology. Basilaia \& Kvavadze (2020) defines online learning as the activity of developing and transferring knowledge from several different places through information and communication technology that uses the internet, audio/video, text communication, and software. In addition, online learning involves learning experiences both synchronously and asynchronously using various devices or devices such as mobile phones and laptops with internet access (Zhu \& Liu, 2020). When the learning process involves direct interaction between the teacher and those being taught at the same time, this is known as Synchronous Teaching. Applications that can be used are Zoom, Skype, and Cisco Webex. Meanwhile, Asynchronous Teaching means learning is carried out indirectly and not at the 
same time. Students can learn at any time because educators have provided material in an application such as the Teacher Room, Zenius, Google Suite for Education, and smart classes (Astini, 2020)

In carrying out learning, lecturers/educators must take advantage of various technologies with various innovations so that online learning runs effectively and efficiently. Many platforms can be used by lecturers to support online learning, from paid to free. In the implementation of online learning, several platforms can be used, namely applications, websites, social networks, or learning management systems (Gunawan et al., 2020). Muhammad (2020) further explains that online learning can be done face-to-face virtual (Google Meet, Zoom, Webex, Teams, and others); with a Learning Management System (LMS) (Study House, Teacher Room, Smart Class, Your School, Zenius.net, and others); or through social media and websites (WhatsApp, YouTube, Instagram, and so on). Some of the platforms are paid and free. Platforms with free access include social media, Youtube, Facebook, WhatsApp, Twitter, Google Classroom, Line, Kahoot, Schoology, etc. (Abidah et al., 2020; Astini, 2020) and Google Meet (Herliandry et al., 2020). From all existing online learning platforms, some platforms can be used to conduct live video conferencing (Zoom) or be used to upload material in the form of video, audio, and images.

However, in choosing a suitable platform, a lecturer needs to consider many things including what courses will be taught and the conditions of the students to be taught. Herliandry et al. (2020) said that although online learning is an effective solution in implementing learning during the Covid-19 pandemic, the conditions for each different region encourage the importance of evaluating the implementation of this learning. This is in line with Zhu \& Liu (2020) which states that during a pandemic, we need to carry out qualitative and quantitative research and evaluate the implementation model of online learning that is or has been carried out.

Lecturers at Tadris Matematika (Department of Mathematics Education) in The Islamic State Institute of Bengkulu (IAIN Bengkulu) have also conducted online / online learning during the Covid-19 pandemic since March 2020. This policy certainly makes lecturers think hard about how to teach mathematics courses online. Besides this is the first experience for lecturers and students, teaching mathematics courses online is not easy. The fact that mathematics is still difficult when taught face-to-face (Santoso, 2020) will certainly be a challenge when online learning occurs. Therefore it is necessary to hold an evaluation related to the online learning process in Tadris Matematika as consideration for improvement in future learning. Therefore, this study will focus on obtaining information about platforms that are effective in teaching mathematics along with the obstacles encountered during online learning during Even Semester in the 2019/2020 Academic Year. 


\section{METHOD}

This research is qualitative research conducted in July as a form of online learning evaluation from mid-March to July in the Mathematics Tadris study program. This qualitative research aims to provide an overview of the object under study based on data collected from the research sample as is without conducting analysis and making general conclusions (Sugiyono, 2010). The description to be obtained is related to the online learning platform and the obstacles encountered regarding the implementation of online learning for the first time at Tadris Mathematika IAIN Bengkulu. The research procedures that will be carried out are planning, preparation, implementation, processing, and presentation. The respondents selected were 90 students of the Tadris Matematika in IAIN Bengkulu. With the purposive sampling method, the samples were selected 32 in the second semester, 35 in the fourth semester, and 23 in the sixth semester.

The data was collected through a questionnaire consisting of closed and open questions that were filled out online using the google form. This survey was conducted to collect data about platform information used by lecturers along with obstacles during online learning in the even semester of the 2019/2020 Academic Year. The qualitative data obtained are then processed by data reduction, display, and concluding (Sugiyono, 2010). Data reduction is data analysis carried out by selecting main things, focusing on important things, and looking for themes and patterns. Other activities that are still included in reducing data, namely activities to focus, summarize, select urgent things. After reducing the data, the presentation of the data is carried out systematically for analysis to provide meaningful information. The next step in qualitative data analysis is drawing conclusions and verification.

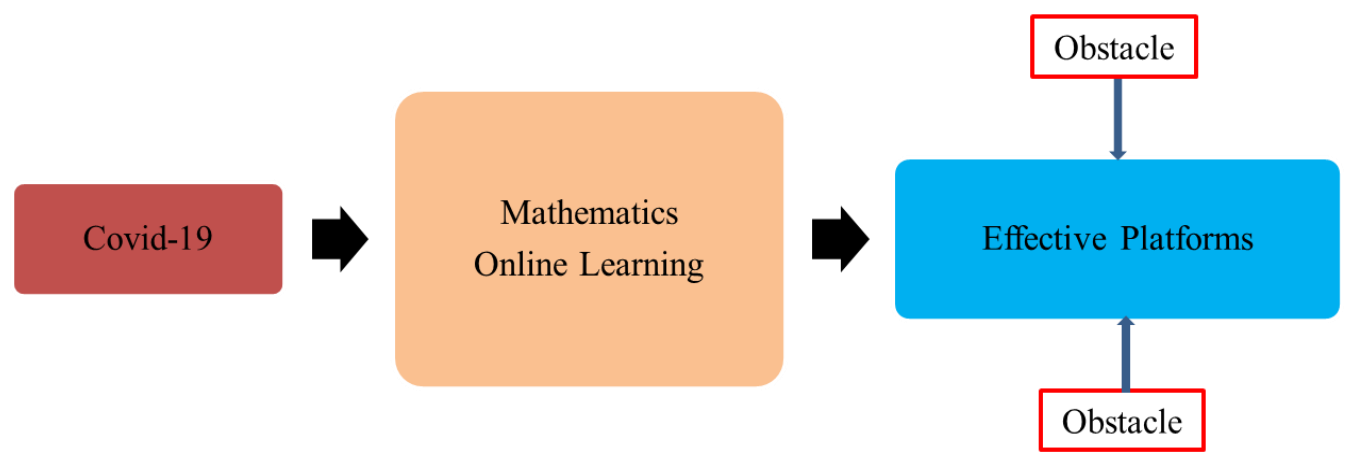

Figure 1. Platform Concept Framework and Obstacles to Online Mathematics Learning 


\section{RESULTS AND DISCUSSION}

Online learning has been carried out in all IAIN Bengkulu study programs since mid-March 2020 including Tadris Matematika Department. 162 students are still actively studying in this department. In the even semester 2019/2020 semesters II, IV, and VI are required to attend advanced lectures from face to face to online/online lectures. Based on the results of the questionnaire on Google Form, it was found that during online learning in the even semester 2019/2020, several courses were mathematical subjects taken by Mathematical Students such as Trigonometry, Middle School Mathematics, Linear Algebra, Basic Statistics (semester II); Calculus 2, Analytical Geometry, Algebraic Structures, Algorithms and Programming, Operations Research (semester IV); and Mathematics for High School Specialization, Real Analysis, Vector Analysis, Transformation Geometry, Ordinary Differential Equations (semester VI).

During online learning of mathematics courses, Tadris Mathematics lecturers take advantage of free and paid platforms and/or social networks such as Google Classroom, WhatsApp Group, Cisco Webex, Google Meet, Zoom meeting, and others. Several students also conveyed that there were lecturers who used not only one platform but combined several platforms. The platforms used by lecturers while teaching Mathematics were 39.6\% WhatsApp Group, 22\% were Google Classroom, 13.2\% Cisco Webex, and 25.2\% others (see Figure 2).

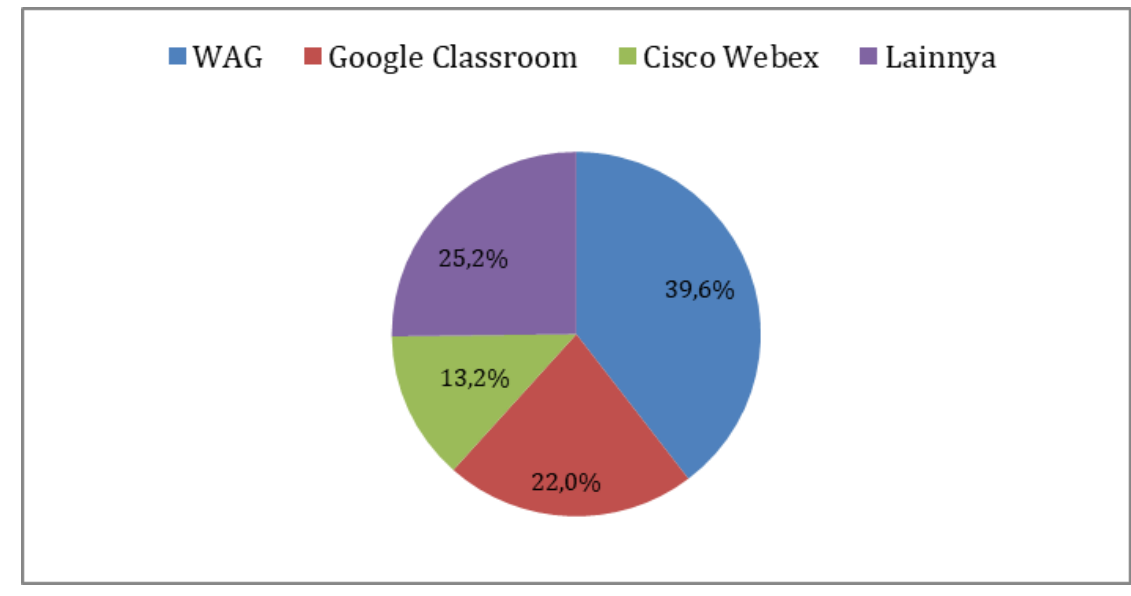

Figure 2. Percentage of Platforms Used During Online Learning

From the findings above, it can be seen that the findings in this study support the findings of Gunawan et al. (2020) and Zhafira et al. (2020) who found that the most important platform used in online learning is the WhatsApp group (WAG). Gunawan found that lecturers used WAG the most, namely $94 \%$ because lecturers and students were already accustomed to using this application. In this application, lectures can be done via WhatsApp group (WAG) either by chat or by sending various types of files into groups. Meanwhile, Zhafira et al. (2020) found that $37 \%$ of lecturers used the WhatsApp platform during learning. However, there is a slight difference between the results of the study by Gunawan et al. with this study and Zhafira et al. In the research of Gunawan 
et al. It was found that 55\% of other lecturers use email, 35\% Google Classroom, 25\% Moodle, $16 \%$ Zoom video conferencing, and $8 \%$ others. Meanwhile, Zhafira et al. found 32\% use Google Classroom, 19\% Zoom, and another 12\%. This research also found that the second most used platform was Google Classroom and then continued to Cisco Webex video conferencing.

The next finding in this study is that of all the platforms used, students feel that the most effective platform for teaching mathematics online is $52.7 \%$ Cisco Webex, 26.4\% WhatsApp Group, 9.9\% Zoom meetings, 5.5\% Google Classroom, and 5.5\% others (see Figure 3).

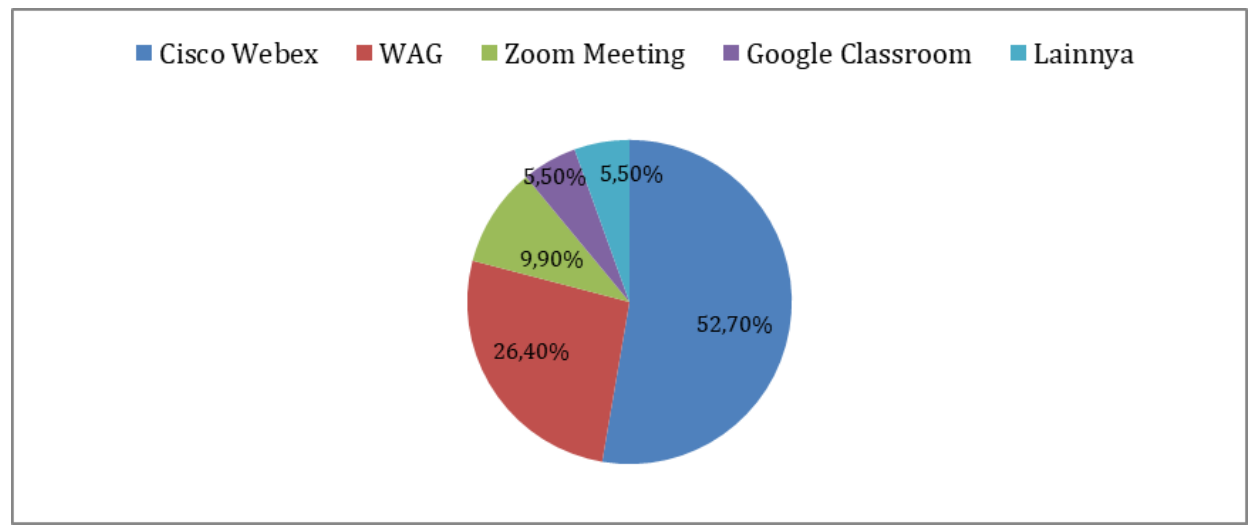

Figure 3. Percentage of Platforms Deemed Effective during Online Learning

The results of this study are in line with Mustakim's (2020) findings that the platforms that students prefer when learning online are Google Classroom (53\%), WhatsApp Group (21\%), Youtube (16\%), Instagram (7\%), and Zoom (3). \%) because this platform does not take up many data packages, it is easy and practical to use. However, it is slightly different from the findings of Zhafira et al. (2020) who have surveyed students. He found that the majority of students during online learning liked semi-two-way (WhatsApp) as much as $68 \%$, while $23 \%$ of students preferred two-way learning (Zoom), and the rest preferred one-way learning by uploading videos.

From follow-up questions regarding the reasons why they consider one platform to be more effective than another, several findings were obtained. Cisco Webex is considered an effective application when learning online mathematics courses due to the availability of several features, namely live conferences, share screens, and whiteboards. Students feel they can better understand the lecture material because the lecturer explains the material using live conferences and whiteboards as if they were in a face-to-face class. When discussing math problems, students can share their answers with a share screen so that the teaching lecturer and other students can see and correct the correctness of the student's answer. Students can also ask questions directly during the online learning process. This is also supported by Mustakim's (2020) findings that mathematics learning should be done via video call / live conference. Behind these benefits, students feel that 
the Cisco Webex platform requires quite a lot of internet data packages, but these are not as much as needed when using Zoom Meeting.

Some students, especially those who live in rural areas, feel that whatApps Group (WAG) is more effective in online learning because this application does not consume a lot of data packages and does not need a strong signal or network. Several features in WAG can make lecturers and students share various types of files (documents, audio, video, and images). Students who are unable to attend can also check the lecture materials stored in the WAG. This is in line with the findings of Sutriyani (2020) who found a positive influence between the use of the WAG platform in elementary mathematics learning courses in online lectures in the PGSD FTIK UNISNU Jepara study program. This can be seen in the learning outcomes obtained by students who are in the good predicate category. By using WAG, lecturers always provide material files in the form of videos, pdf, or power points so that students can study them before class starts so that when lectures take place all students appear to be actively asking, answering, and having opinions. Astini (2020) adds that WhatsApp is considered effective because WhatsApp is one of the most popular communication media used today to conduct conversations using text, voice, and video. In addition, the app is free and offers a simple, safe, reliable message and call exchange experience, available on phones worldwide so you can connect with family friends, anytime and anywhere. This is supported by the statement by Niken, Secretary-General of the Ministry of Communication and Information Technology, who stated that out of 171 million internet users, 83\% are WhatsApp users. This was expressed by Niken in the educational program "Privacy Literacy and Digital Security" at Kominfo Jakarta, Monday, November 18, 2020.

However, some students felt that it was not effective to do online mathematics learning using WAG because the lecturer had limitations in explaining the material (lecturers only distributed material without explanation) or some lecturers explained only through chat. Video, or audio-only. Students also feel that when using WAG, some students sometimes only attend to meet absences and then disappear. This makes the lecturer experience problems in knowing the conditions of the class (who is present and listening to the material) or who is present but is only absent or it could be that online lectures through this WAG are replaced by someone else. Apart from that WhatsApp is a social media app so everyone has multiple WAGs. This causes lecture WAG chats to sometimes be mixed with private chats which cause students not to focus on online learning groups.

The zoom meeting application is considered effective as an online mathematics learning platform because of its live conference and share screen features. However, signal and data packages are the main problems when using Zoom. When the internet network is bad, learning 
feels less effective, the user will be automatically excluded, the sound is unclear and the screen that is shared looks blurry. This results in students having difficulty understanding the material.

Unlike the Google Classroom platform, students feel that learning mathematics feels effective because, in addition to not consuming a lot of data packages, Google Classroom helps archive all lectures neatly. However, the lack of features in the Google classroom makes the material distributed by lecturers sometimes very difficult to understand. Students feel that the Google Classroom features are almost similar to the features in WAG, so they think it's better to use WAG than Google Classroom. In previous research, Maskar and Wulantina (2019) also found a similar thing that online learning using Google Classroom can increase motivation, independence, activeness, and creativity of students and make learning effective and interesting, but unfortunately less efficient because it requires data packages and internet network, especially for access material shared in Google Classroom.

After analyzing some of the respondents' reasons for using the platform during online learning at Tadris Mathematics IAIN Bengkulu, it can be concluded as Table 1.

Table 1. Description of the Use of Online Learning Platforms

\begin{tabular}{|c|c|c|c|c|c|}
\hline Platform & $\begin{array}{l}\text { Access } \\
\text { Fees }\end{array}$ & Data Packages & Networks/Signal & Features & Interactions \\
\hline Cisco Webex & $\begin{array}{l}\text { Free for a } \\
\text { few } \\
\text { minutes, } \\
\text { then paid }\end{array}$ & $\begin{array}{l}\text { Consuming a lot of } \\
\text { data packages }\end{array}$ & $\begin{array}{l}\text { Requiring a strong } \\
\text { network } \\
\text { It is difficult to get a } \\
\text { signal if, in the } \\
\text { village, the lights are } \\
\text { out and the weather } \\
\text { is bad }\end{array}$ & $\begin{array}{l}\text { Share screen } \\
\text { (Documents, } \\
\text { photos, } \\
\text { whiteboards) }\end{array}$ & $\begin{array}{l}\text { Audio and video } \\
\text { (live conference) }\end{array}$ \\
\hline WAG & Free & $\begin{array}{l}\text { Does not consume a } \\
\text { lot of data packages }\end{array}$ & $\begin{array}{l}\text { Does not require a } \\
\text { strong network } \\
\text { Easily accessible in } \\
\text { various places and } \\
\text { conditions }\end{array}$ & $\begin{array}{l}\text { Share } \\
\text { (Documents, } \\
\text { photos, video, and } \\
\text { audio) }\end{array}$ & $\begin{array}{l}\text { Indirect } \\
\text { interaction }\end{array}$ \\
\hline Zoom Meeting & $\begin{array}{l}\text { Free for a } \\
\text { few } \\
\text { minutes, } \\
\text { then paid }\end{array}$ & $\begin{array}{l}\text { Consuming a lot of } \\
\text { data packages }\end{array}$ & $\begin{array}{l}\text { Requiring a strong } \\
\text { network } \\
\text { It is difficult to get a } \\
\text { signal if in the } \\
\text { village, especially } \\
\text { when the lights are } \\
\text { out and the weather } \\
\text { is bad }\end{array}$ & $\begin{array}{l}\text { Share screen } \\
\text { (Documents, } \\
\text { photos, } \\
\text { whiteboards) }\end{array}$ & $\begin{array}{l}\text { Audio and video } \\
\text { (live conference) }\end{array}$ \\
\hline $\begin{array}{l}\text { Google } \\
\text { Classroom }\end{array}$ & Free & $\begin{array}{l}\text { Does not consume a } \\
\text { lot of data packages }\end{array}$ & $\begin{array}{l}\text { Does not require a } \\
\text { strong network } \\
\text { Easily accessible in } \\
\text { various places and } \\
\text { conditions }\end{array}$ & $\begin{array}{l}\text { Share } \\
\text { (Documents, } \\
\text { photos, video, and } \\
\text { audio) }\end{array}$ & $\begin{array}{l}\text { Indirect } \\
\text { interaction }\end{array}$ \\
\hline
\end{tabular}

From Table 1, it can be seen that each platform has advantages and disadvantages. Therefore, a lecturer must consider this in choosing a platform in online mathematics learning. However, Astini (2020) found that the effectiveness of using the platform can be seen from the level of education. He found that applications that are effective for use in the online learning process at the upper-grade level of elementary school are the google classroom application and the 
zoom application, while for the lower classes the application that can be used very effectively is the WhatsApp group application.

The next finding is related to the obstacles experienced by students when learning online (see Figure 4).

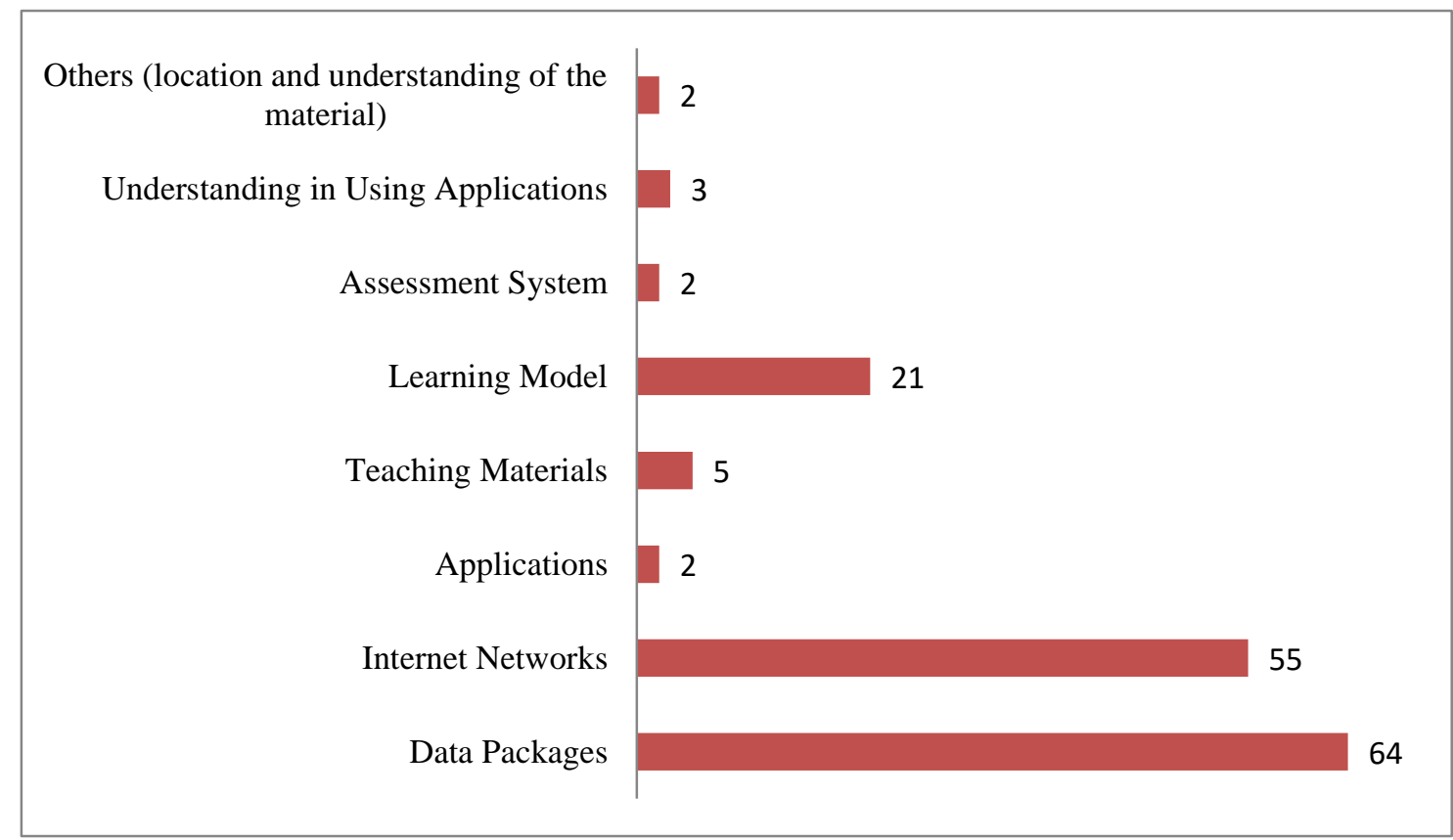

Figure 4. Number of Students Who Find Obstacles during Online Learning

From Figure 4, it can be seen that the majority of students encounter problems related to data packages and internet networks during the online learning process. The expensive data packages price is felt to be very burdensome for students, most of whom come from low-income families. The material presented by the lecturer is mostly from the Youtube channel or in the form of videos where watching or downloading video files takes up more data packages. This makes it difficult for students to understand the material. Sometimes due to limited data packages, they cannot watch or download material from the lecturers. They say that a week can take up to 10-15 GB of data packages. Even though there is already free data packages assistance from the government, this assistance is felt to be insufficient to support the effectiveness of their online learning. Apart from data packages, internet networks or signals are also perceived as a major obstacle in online learning. The conditions where they live in rural areas and even in remote districts make it difficult for them to get a good signal. Even though when the learning process is online, signals are the main factor for students to attend lectures and understand the existing material. Bad signals sometimes make students miss several lecture meetings. Lights out and weather conditions also greatly affect signal strength. When the lights go out or there is a storm, the signal will suddenly disappear.

These findings are in line with the results of previous studies. Mustakim (2020) and Gunawan et al. (2020) found that the most obstacles encountered were limited and expensive 
internet packages and inadequate internet access, while Herliandry et al. (2020) found several obstacles in online learning, namely various regional conditions, the ability of parents to provide facilities, and internet costs. Therefore Herliandry suggested that the implementation of online learning must be by the conditions of the place. Too many assignments and difficulties for students to focus during learning are also major obstacles (Mustakim, 2020).

Some students found obstacles related to how lecturers carry out learning, assessment systems, and understanding material during online learning. The content of the material that students must understand online makes it difficult for them to understand all the material. The addition of assignments at the end of the lecture session in each course is also a problem. Not to mention the lecturers who gave the processing time (task deadlines) in a short time. Therefore, Mustakim (2020) suggests reducing tasks during a pandemic. Students also think that the lack of explanation given by the lecturer creates confusion in understanding the material. Even though there are lecturers who try their best to explain the material during learning, because they are constrained by signals or data packages, students still find it difficult to understand what has been explained. Much of the assessment process is also taken from assignments, but students feel that they find problems doing assignments due to a lack of understanding of the questions being asked and the difficulty of signals or data packages in collecting assignments. These various obstacles make the assessment system for learning mathematics during a pandemic, there should be changes and developments according to the conditions of learners as well as alternative ways of assessment (Santoso, 2020).

The use of applications or various platforms is also an obstacle for students because students are not used to using these applications. Lecturers who use several applications when teaching one subject to become a separate obstacle for students because they have to download several applications that require large memory and data packages. So that complicated applications are also an obstacle in online learning (Mustakim, 2020).

When analyzing the findings of obstacles during online learning during the Covid-19 pandemic, things that must be considered are the factors behind these obstacles. Based on several sources, several factors influence the implementation of online learning, namely: facilities/infrastructure for ownership of equipment and technology (Indahri, 2020; Napitupulu, 2020; Sumarno, 2020; Warsita, 2014); accessibility for internet networks and data packages (Napitupulu, 2020; Sumarno, 2020; Warsita, 2014); location and place of study (Jusuf et al., 2020); implementation system including the accuracy of online learning methods and platforms (Napitupulu, 2020; Nindiati, 2020); teaching competence (Indahri, 2020; Sumarno, 2020; Warsita, 2014); as well as creativity in learning design, learning resources, teaching materials, and assignments (Nindiati, 2020; Saykili, 2018). It can be seen from the results of this study that the 
obstacles found are closely related to the factors that affect online learning, where the relationship can be seen in Figure 5.

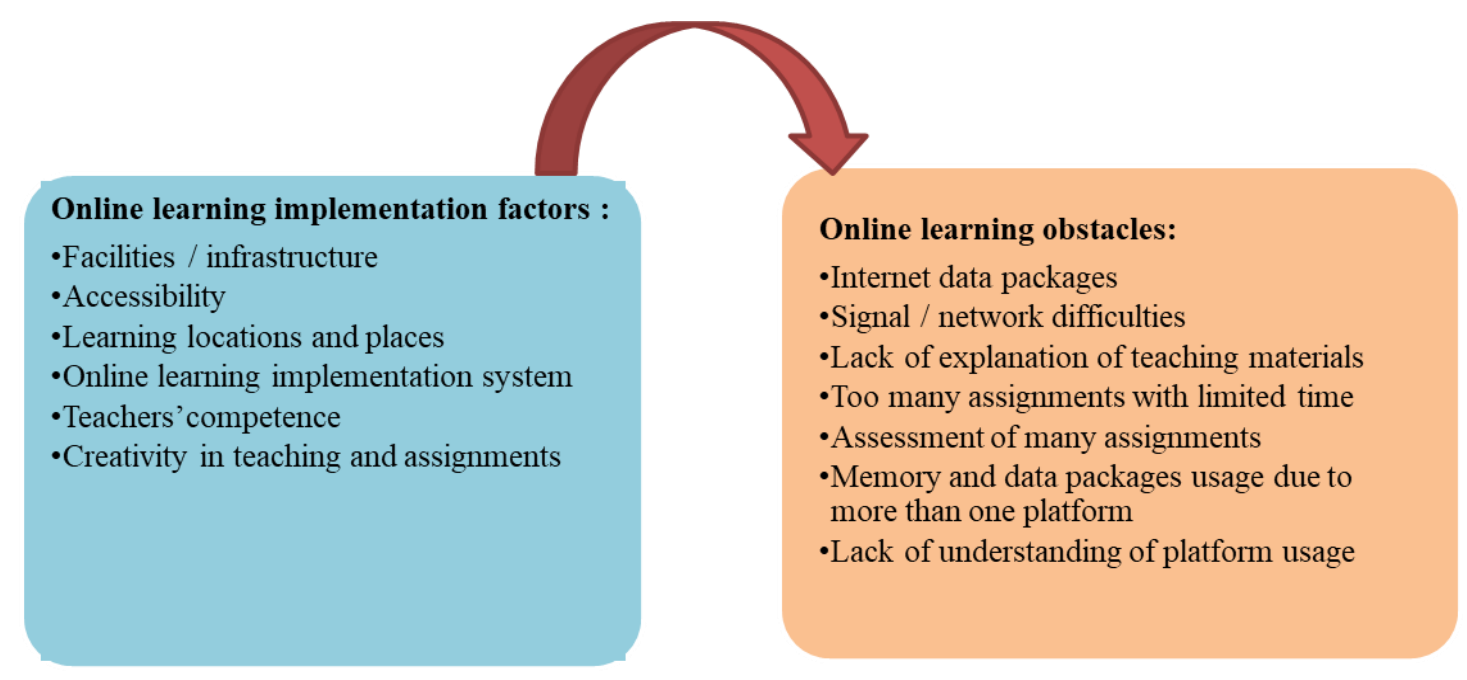

Figure 5. The Relationship between Factors and Obstacles during Online Learning

\section{CONCLUSION}

Online learning has been carried out in various agencies since March 2019 due to the conditions of the Covid-19 pandemic. This is the first time the Tadris Matematika IAIN Bengkulu has implemented online learning so of course, an in-depth evaluation needs to be carried out, especially regarding how the implementation of online learning includes what platforms are considered effective for learning and teaching mathematics and the obstacles encountered during online mathematics learning. After surveying students, it was found that the majority of learning mathematical subjects used WhatsApp, namely $39.6 \%$, but the platform that was felt to be effective in learning mathematics was Cisco Webex (52.7\%). Mathematics material is considered most effective if it is taught using the live video (video conference) feature, share screens for presentations, and whiteboards to add explanations. In the implementation of this online learning, the most important obstacles found by students were networks that were difficult to reach and expensive internet data packages because the majority of them lived in rural areas and from loweconomic families. The number of obstacles found indicates that there is still a need to adopt online learning in the Tadris Matematika program in particular and some educational institutions in general.

\section{REFERENCES}

Abidah, A., Hidaayatullaah, H. N., Simamora, R. M., Fehabutar, D., \& Mutakinati, L. (2020). The Impact of Covid-19 to Indonesian Education and Its Relation to the Philosophy of "Merdeka Belajar." Studies in Philosophy of Science and Education, 1(1). https://doi.org/10.46627/sipose.v1i1.9 
Astini, N. K. S. (2020). Pemanfaatan teknologi informasi dalam pembelajaran tingkat sekolah dasar pada masa pandemi covid-19. Jurnal Lembaga Penjaminan Mutu STKIP Agama Hindu Amlapura, 11(2), 13 25. https://e-journal.stkip-amlapura.ac.id/index.php/jurnallampuhyang/article/view/194/125

Basilaia, G., \& Kvavadze, D. (2020). Transition to Online Education in Schools during a SARS-CoV-2 Coronavirus (Covid-19) Pandemic in Georgia. Pedagogical Research, 5(4). https://doi.org/10.29333/pr/7937

Covid19.go.id. (n.d.). Peta Sebaran Covid-19. Retrieved November 18, 2020, from https://covid19.go.id/peta-sebaran-covid19

Dhawan, S. (2020). Online Learning: A Panacea in the Time of Covid-19 Crisis. Journal of Educational Technology Systems. https://doi.org/10.1177/0047239520934018

Gunawan, Suranti, N. M. Y., \& Fathoroni. (2020). Variations of Models and Learning Platforms for Prospective Teachers During the Covid-19 Pandemic Period. Indonesian Journal of Teacher Education, 1(2), 61-70. https://journal.publication-center.com/index.php/ijte/article/view/95/48

Herliandry, L. D., Nurhasanah, Suban, M. E., \& Kuswanto, H. (2020). Pembelajaran Pada Masa Pandemi Covid-19. Jurnal Teknologi http://journal.unj.ac.id/unj/index.php/itp/article/view/15286/8695

Indahri, Y. (2020). Permasalahan pembelajaran jarak jauh di era pandemi. 12(12), 13-18. https://berkas.dpr.go.id/puslit/files/info_singkat/Info Singkat-XII-12-II-P3DI-Juni-2020-201.pdf

Jusuf, H., Sobari, A., \& Fathoni, M. (2020). Pengaruh Pembelajaran Jarak Jauh Bagi Siswa SMA Di Era Covid-19. Jurnal Kajian Ilmiah, 1(1), 15-24. https://doi.org/10.31599/jki.v1i1.212

Khasanah, D. R. A. U., Pramudibyanto, H., \& Widuroyekti, B. (2020). Pendidikan Dalam Masa Pandemi Covid-19. Jurnal Sinestesia, 10(1), 41-48. https://sinestesia.pustaka.my.id/journal/article/view/44

Maskar, S., \& Wulantina, E. (2019). Persepsi Peserta Didik terhadap Metode Blended Learning dengan Google Classroom. $\quad$ INOMATIKA, $110-121$. https://inomatika.unmuhbabel.ac.id/index.php/inomatika/article/view/156/106

Muhammad, H. (2020). Menyiapkan Pembelajaran di Masa Pandemi: Tantangan dan Peluang. Kemendikbud, $1-22$.

Mustakim. (2020). Efektivitas Pembelajaran Daring Menggunakan Media Online Selama Pandemi Covid-19 pada Mata Pelajaran Matematika. Al asma: Journal of Islamic Education, 2(1), 1-12. http://journal.uinalauddin.ac.id/index.php/alasma/article/view/13646/8447

Napitupulu, R. M. (2020). Dampak pandemi Covid-19 terhadap kepuasan pembelajaran jarak jauh. Jurnal Inovasi Teknologi Pendidikan, 7(1), 23-33. https://doi.org/10.21831/jitp.v7i1.32771

Nindiati, D. S. (2020). Pengelolaan Pembelajaran Jarak Jauh yang Memandirikan Siswa dan Implikasinya Pada Pelayanan Pendidikan. JOEAI (Journal of Education and Instruction), 3(1), 14-20. https://doi.org/https://doi.org/10.31539/joeai.v3i1.1243

Santoso, B. (2020). PROSACH: Sebagai Acuan Pembelajaran Matematika dengan Menggunakan Platform Digital di Masa Pandemik Covid-19. Linear: Journal of Mathematics Education, 1(1), 57-63. https://ejournal.metrouniv.ac.id/index.php/linear/article/view/2224/1659

Saykili, A. (2018). Distance Education: Definitions, Generations, Key Concepts and Future Directions. International Journal of Contemporary Educational Research, 5(1), 2-17. http://search.ebscohost.com/login.aspx?direct=true\&db=eric\&AN=EJ1207516\&site=ehost$\underline{\text { live } \& \text { scope }=\text { site }}$

Sharma, A. K. (2020). Novel Coronavirus Disease (Covid-19). Resonance. https://doi.org/10.1007/s12045$\underline{020-0981-3}$

Sugiyono, D. (2010). Metode penelitian kuantitatif, kualitatif dan R \& D. Bandung: Alfabeta.

Sumarno. (2020). Adaptasi Sekolah Dalam Mengimplementasikan Pembelajaran Jarak Jauh Pada Masa Pandemi Covid-19 (Studi Kasus Smp Muhammadiyah Karanggeneng Kabupaten Lamongan). Jurnal Tarbiyah \& Ilmu Keguruan (JTIK) Borneo, 1(2), 149-162. https://journal.iainsamarinda.ac.id/index.php/JTIKBorneo/article/view/2435/1064 
Sutriyani, W. (2020). Studi Pengaruh Daring Learning Terhadap Minat dan Hasil Belajar Matematika Mahasiswa PGSD Era Pandemi Covid-19. Jurnal Pendidikan Dasar: Jurnal Tunas Nusantara, 2(1), 155 165. https://ejournal.unisnu.ac.id/jtn/article/view/1486

Warsita, B. (2014). Pola Kegiatan Pembelajaran dalam Pendidikan Jarak Jauh. Jurnal Teknodik, 18(1), 7383. http://garuda.ristekbrin.go.id/documents/detail/1456569

WHO. (n.d.). Timeline: WHO's Covid-19 response. https://www.who.int/emergencies/diseases/novelcoronavirus-2019/interactive-timeline/

Zhafira, N. H., Ertika, Y., \& Chairiyaton. (2020). Persepsi Mahasiswa Terhadap Perkuliahan Daring Sebagai Sarana Pembelajaran Selama Masa Karantina Covid-19. Jurnal Bisnis Dan Kajian Strategi Manajemen, 4(1), 37-45. http://jurnal.utu.ac.id/jbkan/article/view/1981/1454

Zhu, X., \& Liu, J. (2020). Education in and After Covid-19: Immediate Responses and Long-Term Visions. Postdigital Science and Education, 2(3). https://doi.org/10.1007/s42438-020-00126-3 